UDC: 582.32

\title{
ACCUMULATION OF HEAVY METALS IN GAMETOPHYTES OF THE EPILITHIC MOSSES
}

\author{
A. I. Polishchuk*, H. L. Antonyak \\ Ivan Franko National University of Lviv, 1, Saksahansky St., Lviv 79005, Ukraine \\ *Corresponding author: e-mail: alex1994pol@gmail.com
}

Polishchuk A. I., Antonyak H. L. Accumulation of heavy metals in gametophytes of the epilithic mosses. Studia Biologica, 2019: 13(2); 21-28 • DOI: https://doi.org/10.30970/sbi.1302.601

Heavy metals are hazardous pollutants in urban atmosphere that are released into the environment mainly as a result of industrial activity and high traffic loads. These substances pose a substantial risk to human health and biota in urban ecosystems. Therefore, environmental monitoring of air pollution with metals by using bioindicator species is of great importance. Bryophytes capable of accumulating heavy metals are widely used as bioindicators of environmental pollution for biomonitoring atmospheric metal deposition. The ability of urban epilithic mosses to accumulate heavy metals has not been studied sufficiently. This invistigation was aimed at studying metal-accumulating ability of Rhynchostegium murale and Schistidium apocarpum mosses collected within the city of Lviv (Western Ukraine), as well as exploring the relationship between the level of anthropogenic load and the accumulation of heavy metals in moss gametophytes. Two polluted sites in the southern part of the city and one control site in the territory of Stryisky Park were analyzed. The content of heavy metals, namely $\mathrm{Cr}, \mathrm{Mn}, \mathrm{Ni}, \mathrm{Pb}$, and $\mathrm{Zn}$, in moss samples was determined by the atomic absorption spectrophotometry using an atomic absorption spectrometer C-115PK Selmi. The results were processed using statistical methods. It was demonstrated that different levels of metal accumulate in Rhynchostegium murale and Schistidium apocarpum mosses. Depending on the concentration in moss gametophytes sampled in the city of Lviv, the studied metals can be arranged in the following order: $\mathrm{Mn}>\mathrm{Zn}>\mathrm{Cr}>\mathrm{Ni}>\mathrm{Pb}$. However, the content of $\mathrm{Mn}$ and $\mathrm{Zn}$ in the $S$. apocarpum moss was found to be considerably higher than in $R$. murale. The gametophytes of both mosses collected in areas subjected to industrial and transport loads in the southern regions of Lviv city had significantly higher concentration of $\mathrm{Pb}$, and $R$. murale also had an elevated $\mathrm{Mn}$ content compared to moss samples collected in green park area. The results of our study suggest that the rate of accumulation of heavy metals in gametophytes of epilithic mosses reflect the level of atmospheric metal deposition in urban areas exposed to the anthropogenic pressures on the environment.

(C) 2019 A. I. Polishchuk et al.; Published by the Ivan Franko National University of Lviv on behalf of Біологічні Студії / Studia Biologica. This is an Open Access article distributed under the terms of the Creative Commons Attribution License (http://www.budapestopenaccessinitiative.org/ and Creative Commons Attribution 4.0 License), which permits unrestricted reuse, distribution, and reproduction in any medium, provided the original work is properly cited.

ISSN 1996-4536 (print) • ISSN 2311-0783 (on-line) • Біологічні Студії / Studia Biologica • 2019 • Том 13/№2 • С. 21-28 
Keywords: heavy metals, bryophytes, urban ecosystems, environmental monitoring, bioindication

\section{INTRODUCTION}

Functioning of urban systems involves a wide range of anthropogenic activities many of which are accompanied by a formation and release of technogenic pollutants into natural environment, primarily into the atmosphere [7, 13]. Adverse environmental and medical consequences of air contamination are felt mostly in densely populated large cities and industrial centers where the main sources of pollution are power plants, metalworking and other industries, as well as high traffic loads [6, 8, 24]. A group of hazardous environmental pollutants includes heavy metals, that pose a substantial risk to human health and biota in urban ecosystems [2, 3, 9, 24].

Usually, the term of heavy metals refers to metal elements with an atomic mass exceeding $40 \mathrm{Da}$ or having a specific density of above $5 \mathrm{~g} / \mathrm{cm}^{3}$ [9]. Heavy metals are known to be constantly present in the environment at background concentrations; however, rapid urbanization and industrialization have altered natural distribution of metals in the environment. Being emitted from stationary and mobile sources in urban settings, metals associate with atmospheric particulate matter and can be transported over a long distance by wind and air currents. Eventually, these substances settle on soil, vegetation and surface water as a result of dry and wet deposition [17, 26]. Due to harmful effects of heavy metal pollution on human health and biodiversity, environmental assessment using bioindicator species is of great relevance.

Bryophytes, including mosses (representatives of Bryophyta division), have been recognized as bioindicators of environmental pollution and biomonitors of atmospheric deposition of heavy metals [11, 18, 19, 21]. Owing to a number of morphological and physiological features, bryophytes are capable of absorbing heavy metals directly from air and precipitation, rather than from a substrate on which they grow. In particular, these characteristics include: 1) lack of cuticle (or its very poor development) and internal vascular system; 2) absence of a true root system; instead, the presence of unicellular rhizoids for fixing to a substrate; 3 ) high accumulation capacity with respect to metals that are absorbed across the entire surface of plant [19,21]. By accumulating heavy metals in their tissues, bryophytes can thereby reflect the level of air contamination.

The bryoflora of Ukraine is quite rich and contains more than 800 identified species [5]. Among them, epilithic bryophytes represent a group of nonvascular plants that colonize natural rocks, stones, and artificial stony substrates. Epiliths can be found on buildings, monuments and other structures of industrial cities, especially in places with high humidity $[20,23]$. However, the ability of urban epilithic mosses to accumulate metals has been less studied compared with other bryophyte groups. Therefore, the aim of this study was to analyze the concentration of heavy metals in gametophytes of Rhynchostegium murale (Hedw.) Schimp. and Schistidium apocarpum Bruch \& Schimp. mosses collected in the territory of the city of Lviv, and to determine possible relationship between the level of technogenic impact on the environment and the accumulation of metals in these epilithic plants.

\section{MATERIALS AND METHODS}

Study area. The study was conducted in the city of Lviv $\left(49^{\circ} 49^{\prime} 48^{\prime \prime} \mathrm{N}, 24^{\circ} 00^{\prime} 51^{\prime \prime} \mathrm{E}\right)$ that is the largest industrial center of Western Ukraine and an important transport junction.

ISSN 1996-4536 (print) • ISSN 2311-0783 (on-line) • Біологічні Студії / Studia Biologica • 2019 • Том 13/№2 • С. 21-28 
Lviv is situated at the edge of the eastern part of the Roztoche Upland at an average altitude of about 290 metres above sea level and covers an area of about $182 \mathrm{~km}^{2}$ [12]. Lviv is a densely populated city with a population of about 730270 inhabitants. The city is characterized by high density of construction and transport infrastructure, as well as highly developed industry. According to information of Lviv City Council, more than 160 industrial enterprises located there operate in various sectors of the economy. However, many of these facilities are the sources of atmosphere pollution. Along with stationary sources of metal emissions, automobile and other modes of transport also represent a source of air contamination.

Sampling sites were chosen taking into account the occurrence of the analyzed species of bryophytes and different levels of anthropogenic load within the city. Two polluted and one control sites were analyzed. Sampling site N1 (control) has been selected in the central part of Stryisky Park that is located in the southern part of Lviv and covers an area of about 52.14 hectares. The park belongs to the Natural Reserve Fund of Ukraine and is a monument of landscape art of national importance. This area can be considered relatively unaffected by technogenic impact due to its remoteness from industrial facilities and busy streets.

Sampling sites N2 and N3 have been selected in areas located along Stryiska Street (about $7.5 \mathrm{~km}$ long) that is the main entrance road to Lviv from the south and characterized by high traffic load. In particular, site N2 was selected at the beginning of the street, not far from the central part of the city, and site N3 was located in the area adjacent to the middle part of Stryiska Street in the southern part of Lviv. Traditionally, this area belongs to the industrial districts of the city and is influenced by a number of industrial enterprises, such as Kameniar Lviv Stone Processing Plant, Lviv Armor Vehicle Factory, Scientific-Production Company Electron-Karat and others. Consequently, sampling sites N2-N3 represent the polluted areas in the city of Lviv.

Sample preparation and analysis. The analyzed bryoflora species are representatives of the division Bryophyta, class Bryopsida. Rhynchostegium murale (Hedw.) Schimp. moss belongs to the Brachytheciaceae family of the order Hypnales, and Schistidium apocarpum (Hedw.) Bruch \& Schimp. belongs to the Grimmiaceae family of the Grimmiales order. Both species are common in Ukraine [5] and other European countries [16, 20, 23].

The material under study was collected during the vegetation period. Sampling and sample preparation were carried out using routine methods [22]. In laboratory conditions, plant samples were cleaned of any extraneous materials, washed with distilled water, and dried at room temperature. For identification of moss species, samples were analyzed using an XS 6220 stereoscopic microscope.

The content of heavy metals, namely chromium ( $\mathrm{Cr}$ ), manganese $(\mathrm{Mn})$, nickel (Ni), lead $(\mathrm{Pb})$ and zinc $(\mathrm{Zn})$ in moss samples was determined using atomic absorption spectrophotometry. Preparation of test material before analysis was carried out in accordance with standard methods [14]. The measurements were performed using the atomic absorption spectrometer C-115PK Selmi (Ukraine).

Samples of moss material were taken in triplicate at each sampling site in different seasons. For statistical analysis of the results, the arithmetic mean and its standard deviation (M $\pm S$.D.) were calculated. When comparing data groups, a significance of differences was evaluated using Student's $t$-test, and data were considered reliable at $p<0.05$ [25].

ISSN 1996-4536 (print) • ISSN 2311-0783 (on-line) • Біологічні Студії / Studia Biologica • 2019 • Том 13/№2 • С. 21-28 


\section{RESULTS AND DISCUSSION}

The results of conducted study show that metals accumulated in moss gametophytes can be arranged in order of decreasing concentration in the following range: $\mathrm{Mn}>\mathrm{Zn}>\mathrm{Cr}>\mathrm{Ni}>\mathrm{Pb}$. Although such a distribution pattern was observed for both bryophyte species, the content of two metals, namely $\mathrm{Mn}$ and $\mathrm{Zn}$, differed considerably between the gametophytes of Rhynchostegium murale and Schistidium apocarpum (Fig. 1). Concentration of these metals in $S$. apocarpum moss was $1.87(p<0.01)$ and 1.42 times $(p<0.05)$ higher, respectively, compared with $R$. murale. Concentrations of other metals did not differ significantly between the analyzed moss species.

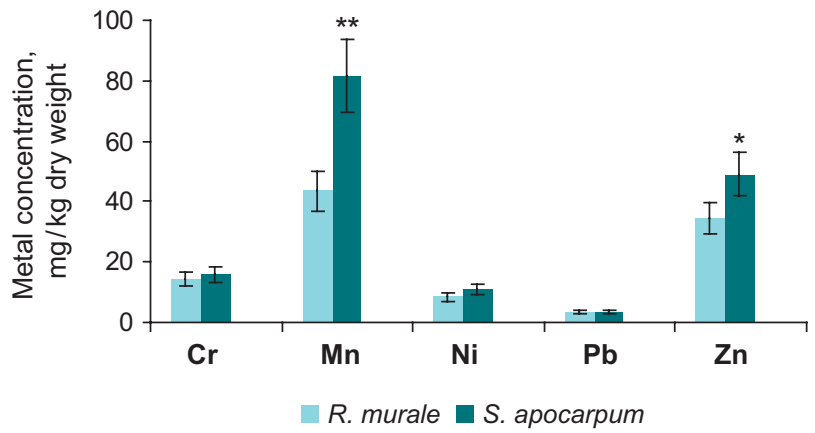

Fig. 1. Concentration of heavy metals in gametophytes of Rhynchostegium murale and Schistidium apocarpum mosses collected in the city of Lviv (pooled data from the sampling sites)

Comment: in this and subsequent figures, the marks $\left({ }^{*}\right)$ and $\left({ }^{* *}\right)$ indicate statistically significant differences between the analyzed indices $\left({ }^{*}-p<0.05 ;{ }^{* *}-p<0.01\right)$

Рис. 1. Концентрація важких металів у гаметофрітах мохів Rhynchostegium murale та Schistidium apocarpum, зібраних у місті Львові (об’єднані дані з місць відбору проб)

Примітка: на цьому та наступних рисунках позначки $\left(^{*}\right)$ i $\left(^{* *}\right)$ вказують на статистично вірогідні відмінності між аналізованими показниками $\left({ }^{*}-p<0,05 ;{ }^{* *}-p<0,01\right)$

In order to explore the relationship between the atmospheric metal deposition and the accumulation of heavy metals in mosses, data on the concentrations of metals in plant material collected in the areas adjacent to Stryiska Street (sampling sites N 2-3 with a high level of anthropogenic load) were combined. Subsequently, these data were compared with the results obtained for mosses collected in Stryisky Park. According to the results of a comparative analysis, the concentration of several metals in moss samples from Stryiska Street reached considerably higher values than in samples from park area. In particular, the concentrations of $\mathrm{Mn}$ and $\mathrm{Pb}$ in $R$. murale gametophytes sampled in areas adjacent to Stryiska Street were 1.57 times $(p<0.05)$ and 1.7 times $(p<0.05)$ higher, respectively, than in moss material from Stryisky Park (Fig. 2). However, no statistically significant differences were found in the $\mathrm{Cr}$, Ni, and $\mathrm{Zn}$ contents between moss samples from the analyzed areas, despite the fact that the mean concentrations of these metals in $R$. murale gametophytes from Stryiska Street were slightly higher compared to plants from park territory.

As regards to $S$. apocarpum, a significant difference was found in the concentration of $\mathrm{Pb}$, namely, 1.64 times $(\mathrm{p}<0.05)$, between the samples taken in the areas adjacent to Stryiska Street and in the territory of Stryisky Park (Fig. 3). As in the case of R. murale moss, the mean concentrations of other metals (in particular, Mn) tended to increase in S. apocarpum gametophytes collected in the vicinity of Stryiska Street.

ISSN 1996-4536 (print) • ISSN 2311-0783 (on-line) • Біологічні Студії / Studia Biologica • 2019 • Том 13/№2 • С. 21-28 


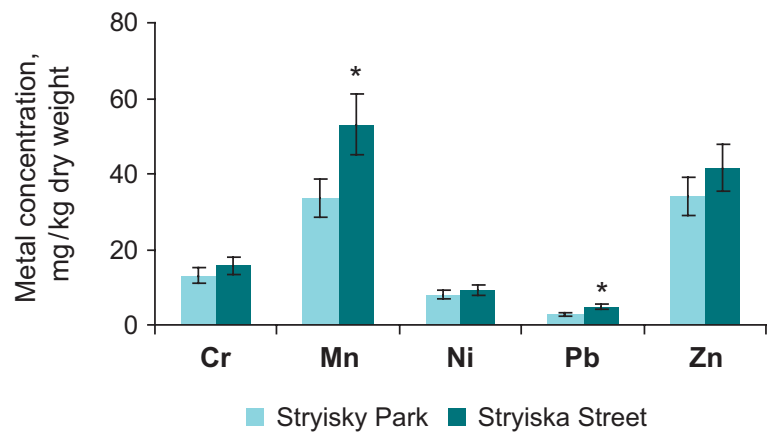

Fig. 2. Concentration of heavy metals in the gametophyte of Rhynchostegium murale moss collected in Stryisky Park and in the areas adjacent to Stryiska Street in the city of Lviv

Рис. 2. Концентрація важких металів у гаметофріті моху Rhynchostegium murale, зібраного в Стрийському парку та на територіях, прилеглих до вулиці Стрийської у місті Львові

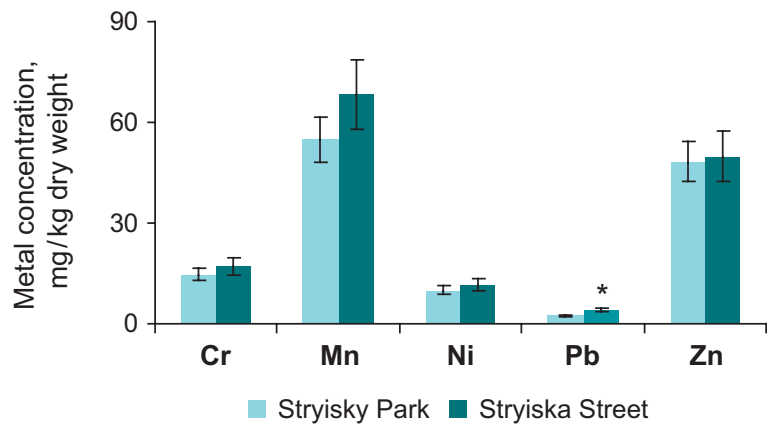

Fig. 3. Concentration of heavy metals in the gametophyte of Schistidium apocarpum collected in Stryisky Park and in the areas adjacent to Stryiska Street in the city of Lviv

Рис. 3. Концентрація важких металів у гаметофіті моху Schistidium apocarpum, зібраного в Стрийському парку та на територіях, прилеглих до вулиці Стрийської у місті Львові

The results of conducted study indicate that the rate of metal accumulation in gametophytes of mosses is apparently associated with the level of anthropogenic load in southern regions of Lviv that belong to the industrial areas of the city. In addition, Stryiska Street itself is subjected to a high traffic load (according to our observations, the traffic intensity is about 700 vehicles per hour in the daytime). Obviously, the industrial facilities operating in the studied area and vehicle traffic are sources of heavy metal emissions into the air, contributing to an increase in metal concentrations in terrestrial vegetation, including bryophytes. Among the analyzed metals, this primarily relates to $\mathrm{Pb}$, whose concentration in gametophytes of both species of mosses from the areas adjacent to Stryiska Street reaches significantly higher values compared to samples from Stryisky Park. Furthermore, $R$. murale moss sampled in the areas exposed to industrial and traffic loads was featured by a significantly higher $\mathrm{Mn}$ concentration compared to moss collected in park area, relatively remote from the industrial impact. Both of these metals are known to be contained in the industrial emissions and non-exhaust vehicular dust (metal corrosion, tire, brake and clutch wear, wear of the roadway, etc.) $[1,10,24]$; besides, automobile exhaust is an additional source of heavy metals, including $\mathrm{Pb}$, in the atmosphere $[4,15]$. Lead and manganese are among the representative metals whose concentrations in the environment can be used as reliable indices of the anthropogenic pollution [10]. Therefore, the obtained

ISSN 1996-4536 (print) • ISSN 2311-0783 (on-line) • Біологічні Студії / Studia Biologica • 2019 • Том 13/№2 • С. 21-28 
data on the increment of $\mathrm{Pb}$ and $\mathrm{Mn}$ in moss samples collected in areas of technogenic stresses indicate air pollution by these metals in the southern part of the city of Lviv.

In general, the results of the study suggest that epilithic mosses, capable of accumulating heavy metals, can reflect the level of air pollution by metals in areas exposed to industrial and transport loads, similar to other ecological group of bryophytes. However, species differences in metal-accumulating capacities of bryophytes should be considered when using these plants as biomonitors of the atmospheric deposition of heavy metals in urban ecosystems.

\section{CONCLUSIONS}

The results of the conducted study show that the Rhynchostegium murale and Schistidium apocarpum mosses have different capacities for accumulating heavy metals. Depending on the concentration in moss gametophytes collected in the city of Lviv, the studied metals can be arranged in the following order: $\mathrm{Mn}>\mathrm{Zn}>\mathrm{Cr}>\mathrm{Ni}>\mathrm{Pb}$. However, the content of $\mathrm{Mn}$ and $\mathrm{Zn}$ in the $\mathrm{S}$. apocarpum moss was found to be considerably higher than in $R$. murale. Gametophytes of both mosses collected in areas subjected to industrial and transport loads in the southern part of Lviv had significantly higher concentrations of $\mathrm{Pb}$, and $R$. murale also had an elevated Mn content compared to samples collected in park area. The obtained results suggest that the rate of accumulation of heavy metals in gametophytes of the epilithic mosses can indicate the level of atmospheric pollution in urban settings.

1. Adamiec E., Jarosz-Krzemińska E., Wieszała R. Heavy metals from non-exhaust vehicle emissions in urban and motorway road dusts. Environmental Monitoring and Assessment, 2016; 188: 369.

[DOI: https://doi.org/10.1007/s10661-016-5377-1]

2. Antonyak H.L., Bagday T.V., Pershyn O.I., Bubys O.E., Panas N.E., Oleksyuk N.P. Metals in aquatic ecosystems and their influence on hydrobionts. Animal Biology, 2015; 17(2): 9-24. (In Ukrainian) [Google Scholar]

3. Antonyak H.L., Mamchur Z.I., Pershyn O.I., Bubys O.E., Kordosh T.V. Biological availability of metals and their accumulation in plant tissues. Bulletin of Problems of Biology and Medicine, 2015; 2(123): 11-16. (In Ukrainian)

[Google Scholar]

4. Awofolu O.R. Impact of automobile exhaust on levels of lead in a commercial food from bus terminals. J. Appl. Sci. Environ. Manage., 2004; 8(1): 23-27.

[DOI: https://doi.org/10.4314/jasem.v8i1.17221]

5. Boiko M.F. A Checklist of Bryobionta of Ukraine. Kherson: Ailant, 2008. 229 p. (In Ukrainian) [Google Scholar]

6. Bourdrel T., Bind M.A., Béjot Y., Morel O., Argacha J.F. Cardiovascular effects of air pollution. Archives of Cardiovascular Diseases, 2017; 110(11): 634-642.

[DOI: https://doi.org/10.1016/j.acvd.2017.05.003]

7. Breuste J.H., Anwar M.M., Nawaz R., Rani M. Urban Ecosystems: Functions, Value and Management. In: Ecosystem Functions and Management (Sandhu H., ed.). Springer Int. Publ. AG, 2017: 123-154.

[DOI: https://doi.org/10.1007/978-3-319-53967-6_7]

8. Chernychenko I.O., Lytvychenko O.M., Sovertkova L.S., Tsymbaliuk S.M. Cancer risk assessment for the population of the industrial cities of Ukraine. Environment \& Health, 2017; 2: 17-22. (In Ukrainian)

[Google Scholar]

ISSN 1996-4536 (print) • ISSN 2311-0783 (on-line) • Біологічні Студії / Studia Biologica • 2019 • Том 13/№2 • С. 21-28 
9. Järup L. Hazards of heavy metal contamination. British Medical Bulletin, 2003; 68(1): 167-182. [DOI: https://doi.org/10.1093/bmb/ldg032]

10. Kabir E., Ray S., Kim K.H., Yoon H.O., Jeon E.C., Kim Y.S., Cho Y.S., Yun S.T., Brown R.J.C. Current status of trace metal pollution in soils affected by industrial activities. Scientific World Journal, 2012; 2012: 916705.

[DOI: https://doi.org/10.1100/2012/916705]

11. Mamchur Z. Urbanophilic epiphytic mosses of Lviv city. Visnyk of Lviv University. Biology series, 2010; 54: 115-122. (In Ukrainian)

[Google Scholar]

12. Matolych B.M. Ecological Atlas of Lviv Region. Lviv, 2007: 67 p. (In Ukrainian) [Google Scholar]

13. Naeini F.Y., Azimzadeh H., Arani A.M., Sotoudeh A., Kiani B. Ecological risk assessment of heavy metals from cement factory dust. Environmental Health Engineering and Management Journal, 2019; 6(2): 129-137.

[DOI: https://doi.org/10.15171/EHEM.2019.15]

14. Ogunkunle C.O., Ziyath A.M., Rufai S.S., Fatoba P.O. Surrogate approach to determine heavy metal loads in a moss species - Barbula lambaranensis. Journal of King Saud University. - Science, 2016; 28(2): 193-197.

[DOI: https://doi.org/10.1016/j.jksus.2015.11.002]

15. Ozdemir $\mathrm{H}$. Mitigation impact of roadside trees on fine particle pollution. Science of the Total Environment, 2019; 659: 1176-1185.

[DOI: https://doi.org/10.1016/j.scitotenv.2018.12.262]

16. Plášek V. Bryophytes in the woods. Field guide for foresters and valuators. Warsaw: State Forests Information Center, 2013: 130 p.

[Google Scholar]

17. Popoola L.T., Adebanjo S.A., Adeoye B.K. Assessment of atmospheric particulate matter and heavy metals: a critical review. Int. J. Environ. Sci. Technol., 2018; 15: 935.

[DOI: https://doi.org/10.1007/s13762-017-1454-4]

18. Qarri F., Lazo P., Allajbeu S., Bekteshi L., Kane S., Stafilov T. The evaluation of air quality in Albania by moss biomonitoring and metals atmospheric deposition. Archives of Environmental Contamination and Toxicology, 2019; 76: 554-571.

[DOI: https://doi.org/10.1007/s00244-019-00608-x]

19. Stanković J.D., Sabovljević A.D., Sabovljević M.S. Bryophytes and heavy metals: a review. Acta Botanica Croatica, 2018: 77(2): 109-118.

[DOI: https://doi.org/10.2478/botcro-2018-0014]

20. Stebel A. Contribution to the bryoflora of the Wiśnickie Foothills (Western Carpathians, Poland). Acta Musei Silesiae, Scientiae Naturales, 2015; 64:131-139.

[DOI: https://doi.org/10.1515/cszma-2015-0019]

21. Tessier L., Boisvert J.L. Performance of terrestrial bryophytes as biomonitors of atmospheric pollution. A review. Toxicological and Environmental Chemistry, 1999. 68: 179-220. [DOI: https://doi.org/10.1080/02772249909358655]

22. Vanderpoorten A., Papp B., Gradstein R. Sampling of bryophytes. Chapter 13. In: Manual on Field Recording Techniques and Protocols for All Taxa Biodiversity Inventories (Eymann J., Degreef J., Häuser Ch., Monje J.C., Samyn Y., Spiegel D.V., eds.). Belgian Development Cooperation; UK Joint Nature Conservation Committee, 2010: 331-345.

[Google Scholar]

23. Vellak K., Ingerpuu N., Leis M., Ehrlich L. Annotated checklist of Estonian bryophytes. Folia Cryptogamica Estonica, 2015; 52:109-127

[DOI: https://doi.org/10.12697/fce.2015.52.14]

24. Wan D., Yang G., Yang J., Zhan C. Ecological risks and spatial distributions of heavy metals in Beijing atmospheric dust. Pol. J. Environ. Stud., 2018; 27(2): 881-887.

[DOI: https://doi.org/10.15244/pjoes/76285]

ISSN 1996-4536 (print) • ISSN 2311-0783 (on-line) • Біологічні Студії / Studia Biologica • 2019 • Том 13/№2 • С. 21-28 
25. Welham S.J., Gezan S.A., Clark S.J., Mead A. Statistical Methods in Biology. Design and Analysis of Experiments and Regression. Taylor \& Francis Group, LLC, 2015: 568 p. [DOI: https://doi.org/10.1201/b17336]

26. Zhang L., Gao M., Cui J., Yang F., Wang H., Fu C., Huang Y. Wet deposition of trace metals at a typical urban site in Southwestern China: fluxes, sources and contributions to aquatic environments. Sustainability, 2018; 10: 69.

[DOI: https://doi.org/10.3390/su10010069]

\section{АКУМУЛЯЦІЯ ВАЖКИХ МЕТАЛІВ У ГАМЕТОФІТАХ ЕПІЛІТНИХ МОХІВ}

\section{О. І. Полішук, Г. Л. Антоняк}

Львівський національний університет імені Івана Франка вул. Грушевського, 4, Львів 79005, Україна

* Кореспондуючий автор: e-mail: alex1994pol@gmail.com

Важкі метали належать до небезпечних забруднювачів атмосфери, які потрапляють у навколишнє середовище переважно внаслідок промислової діяльності і транспортного навантаження. Забруднення повітря металами становить істотний ризик здоров'ю людини та стану біоти в урбоекосистемах. Тому важливе значення має екологічний моніторинг забруднення повітря металами з використанням видівбіоіндикаторів. Мохоподібні, здатні накопичувати важкі метали, широко використовують як біоіндикатори стану довкілля та біомонітори рівня забруднення металами атмосфрерного повітря. Однак здатність епілітних мохів, розповсюджених на території міст, до акумуляції металів вивчена недостатньою мірою. Метою роботи було дослідити рівень акумуляції важких металів у гаметофітах мохів Rhynchostegium murale i Schistidium apocarpum, зібраних у м. Львові, та проаналізувати зв'язок між рівнем антропогенного навантаження та накопиченням металів у цих видах бріофітів. На території досліджень були вибрані дві забруднені ділянки у південній частині міста й одна ділянка у Стрийському парку, яку приймали за контроль. Концентрацію металів (Cr, Mn, Ni, Pb i Zn) у рослинних зразках визначали атомно-абсорбційною спектрофотометрією за допомогою атомно-абсорбційного спектрометра C-115PK Selmi. Результати опрацьовували з використанням статистичних методів. У процесі досліджень встановлено різний рівень накопичення металів у мохах Rhynchostegium murale та Schistidium apocarpum. Залежно від концентрації у гаметофітах обох видів мохів, досліджувані метали можна розташовувати у такому порядку: $M n>Z n>$ $\mathrm{Cr}>\mathrm{Ni}>\mathrm{Pb}$. Однак вміст Mn i Zn у гаметофіті моху S. apocarpum значно вищий, ніж у гаметофріті $R$. murale. У гаметофрітах обох видів мохів, зібраних у районах південної частини м. Львова, які зазнають промислового і транспортного навантаження, встановлено вірогідно більшу концентрацію $\mathrm{Pb}$, а в гаметофіті $R$. murale - ще й підвищений вміст Mn, ніж у рослинному матеріалі, зібраному на парковій території. Результати дослідження свідчать про те, що інтенсивність акумуляції важких металів у гаметофітах епілітних мохів може відображати рівень забруднення атмосфери металами в міських районах, які зазнають техногенного навантаження.

Ключові слова: мохоподібні, важкі метали, урбоекосистеми, екологічний моніторинг, біоіндикація

Одержано: 11.10.2019

ISSN 1996-4536 (print) • ISSN 2311-0783 (on-line) • Біологічні Студії / Studia Biologica • 2019 • Том 13/№2 • С. 21-28 